Article

\title{
Numerical Study on the Homogeneous Reactions of Mercury in a 600 MW Coal-Fired Utility Boiler
}

\author{
Qiang Lyu ${ }^{1}$, Chang'an Wang ${ }^{1, *}$, Xuan Liu ${ }^{2,3}$ and Defu Che ${ }^{1}$ \\ 1 State Key Laboratory of Multiphase Flow in Power Engineering, School of Energy and Power Engineering, \\ Xi'an Jiaotong University, Xi'an 710049, China; qianglv@xjtu.edu.cn (Q.L.); dfche@mail.xjtu.edu.cn (D.C.) \\ 2 College of Environmental Science and Engineering, Hunan University, Changsha 410082, China; \\ liuxuanne@hnu.edu.cn \\ 3 Key Laboratory of Environmental Biology and Pollution Control, Hunan University, Ministry of Education, \\ Changsha 410082, China \\ * Correspondence: changanwang@mail.xjtu.edu.cn
}

check for updates

Citation: Lyu, Q.; Wang, C.; Liu, X.; Che, D. Numerical Study on the Homogeneous Reactions of Mercury in a 600 MW Coal-Fired Utility Boiler. Energies 2022, 15, 446. https:// doi.org/10.3390/en15020446

Academic Editor: Giancarlo Sorrentino

Received: 6 December 2021

Accepted: 7 January 2022

Published: 9 January 2022

Publisher's Note: MDPI stays neutral with regard to jurisdictional claims in published maps and institutional affiliations.

Copyright: (C) 2022 by the authors. Licensee MDPI, Basel, Switzerland. This article is an open access article distributed under the terms and conditions of the Creative Commons Attribution (CC BY) license (https:// creativecommons.org/licenses/by/ $4.0 /)$

\begin{abstract}
The homogeneous oxidation of elemental mercury $\left(\mathrm{Hg}^{0}\right)$ can promote $\mathrm{Hg}$ pollution control in coal-fired power plants, while the mechanisms and quantitative contributions of homogeneous reactions in $\mathrm{Hg}^{0}$ oxidation, especially the reactions between $\mathrm{Hg}$ and chlorine $(\mathrm{Cl})$, are still unclear. Here, a numerical study on the homogeneous reactions of $\mathrm{Hg}$ was conducted within a $600 \mathrm{MW}$ tangentially fired boiler for the first time. A novel $\mathrm{Hg}$ sub-model was established by coupling the thermodynamics, reaction kinetics and fluid dynamics. The results showed that the higher $\mathrm{Cl}$ content in coal was beneficial to the oxidation of $\mathrm{Hg}^{0}$. The homogeneous reactions of $\mathrm{Hg}$ mainly occurred in the vertical flue pass at low temperature. $\mathrm{Hg}^{0}$ was still the dominant $\mathrm{Hg}$-containing species at the boiler exit, and the concentration of mercury chloride $\left(\mathrm{HgCl}_{2}\right)$ was the highest among the oxidized mercury. When low-Cl coal was fired, the addition of a small amount of chlorine species into the boiler at the burnout area increased the ratio of $\mathrm{HgCl}_{2}$ by over 16 times without causing serious chlorine corrosion problems.
\end{abstract}

Keywords: mercury; computation fluid dynamics (CFD); homogeneous reaction; utility boiler; chlorine

\section{Introduction}

Coal-fired utility boilers are the predominant anthropogenic mercury $(\mathrm{Hg})$ sources in many regions around the world [1,2]. Mercury is released from coal during the combustion process, with only about $2 \%$ of mercury remaining in the bottom slag. Mercury in flue gas mainly exists in three forms: gaseous elemental mercury $\left(\mathrm{Hg}^{0}\right)$, gaseous oxidized mercury $\left(\mathrm{Hg}^{2+}\right)$ and particulate mercury $\left(\mathrm{Hg}_{\mathrm{p}}\right)$ [3-5]. Among them, gaseous oxidized mercury has high solubility and can be removed in wet flue gas desulfurization devices. Particulate mercury can be collected using particulate matter control devices, such as electrostatic precipitators (ESPs) and fabric filters (FFs). As a result, most mercury emitted to the atmosphere from coal-fired power plants is in the form of gaseous elemental mercury, which is difficult to remove. Gaseous elemental mercury is the only stable form of mercury in the temperature range of furnaces $\left(1050 \sim 1400{ }^{\circ} \mathrm{C}\right)$. During the combustion process, the flue gas temperature decreases gradually as the flue gas flows. Part of $\mathrm{Hg}^{0}$ will then be oxidized into $\mathrm{Hg}^{2+}$ by other flue gas components, while some of the $\mathrm{Hg}^{0}$ will be captured by fly ash particles [6]. Some scholars have carried out thermodynamic equilibrium analyses on mercury species and have reported that only $\mathrm{Hg}^{0}$ can exist stably when the temperature is higher than $750{ }^{\circ} \mathrm{C}$, while all $\mathrm{Hg}^{0}$ will be oxidized into $\mathrm{Hg}^{2+}$ if the temperature is below $450{ }^{\circ} \mathrm{C}[7,8]$. However, the measured data show that $\mathrm{Hg}^{0}$ still occupies a large proportion of $\mathrm{Hg}$ emitted from the flue gas because the oxidation process of $\mathrm{Hg}^{0}$ is limited by the kinetic factors $[9,10]$. For example, Chen et al. reported that the fractions of gaseous elemental mercury, gaseous oxidized mercury and particulate 
mercury before ESP/FF are $10.4 \% \sim 93.2 \%, 3.7 \% \sim 44.3 \%$ and $1.3 \% \sim 59.5 \%$, respectively [9]. The migration of mercury species in coal-fired boilers is affected by the coal type and boiler operating conditions [7,11-13]. Additionally, the concentrations of $\mathrm{HCl}, \mathrm{NO}_{x}, \mathrm{SO}_{2}$ and other components in flue gas also greatly influence the oxidation reactions of $\mathrm{Hg}^{0}[12,14]$.

The oxidation processes of $\mathrm{Hg}^{0}$ in flue gas include homogeneous oxidation and heterogeneous oxidation. Homogeneous oxidation refers to the redox reactions between $\mathrm{Hg}^{0}$ and flue gas components within the boiler. Heterogeneous oxidation occurs on the surfaces of adsorbents or catalysts, for which the reaction temperature is even lower. The influence of $\mathrm{HCl}$ on the homogeneous oxidation of $\mathrm{Hg}^{0}$ was studied by Sliger et al. [15]. The results showed that increasing the concentration of $\mathrm{HCl}$ could increase the temperature zone of homogeneous $\mathrm{Hg}$ reactions significantly, which meant that $\mathrm{Hg}^{0}$ could be oxidized earlier in the boiler. Galbreath et al. conducted a bench-scale study on a $7 \mathrm{~kW}$ coal combustion system and found that the $\mathrm{HCl}$ addition could enhance the oxidation of $\mathrm{Hg}^{0}$ significantly [16]. Wang et al. focused on the heterogeneous oxidation of $\mathrm{Hg}^{0}$ and compared the influences of $\mathrm{NaCl}, \mathrm{CaCl}_{2}$ and $\mathrm{HCl}$ additions [17]. However, compared with the extensive investigations on heterogeneous mercury reactions, the research on the homogeneous reactions of mercury in a full-scale utility boiler is still insufficient $[18,19]$. The distributions of the mercury-related species inside the furnace and flue pass are yet to be revealed. Considering the decisive role of the forms of mercury species in choosing the mercury removal approach, it is necessary to investigate the homogeneous reactions between mercury and other flue gas components for mercury emission control from coal-fired power plants.

Because of the extremely low concentrations of $\mathrm{Hg}$ and its compounds, it is difficult to carry out experimental studies on the homogeneous reaction of mercury. The computational fluid dynamics (CFD) method is an alternative way to investigate the homogeneous reactions of $\mathrm{Hg}$ in coal-fired utility boilers. Taking into account the vital influences of $\mathrm{Hg}-\mathrm{Cl}$ reactions on the homogeneous oxidation of $\mathrm{Hg}^{0}$, we conducted this numerical study with the following aims: (1) revealing the influence of the chlorine content in coal on the homogeneous reactions of $\mathrm{Hg}$; (2) evaluating the quantitative impacts of the addition of $\mathrm{Cl}$-containing species on the homogeneous oxidation of $\mathrm{Hg}^{0}$ inside a full-scale boiler.

For the first time, a novel mercury sub-model was established in a full-scale tangentially coal-fired boiler to achieve the coupling of thermodynamics, reaction kinetics and fluid dynamics. The thermodynamics data for mercury species and the kinetics data for the elemental reactions are needed to conduct the simulation of the homogeneous mercury reactions. In addition to the homogeneous reactions of $\mathrm{Hg}$, the flow field, the temperature field and the flue gas component distribution within the boiler were also analyzed. The results of this work are of significance in understanding the mechanisms of homogeneous $\mathrm{Hg}$ reactions and will lay a foundation for efficient mercury pollution control in coal-fired utility boilers.

\section{Utility Boiler and Input Parameters}

\subsection{Boiler Description and Mesh Generation}

Supercritical tangentially boilers are widely used in coal-fired power plants because of their good flame fullness and high combustion efficiency [20-23]. Therefore, a $600 \mathrm{MW}$ supercritical tangentially fired boiler was chosen in this study, as shown in Figure 1a. The width, depth and elevation of the furnace of this boiler were $18,816 \mathrm{~mm}, 17,696 \mathrm{~mm}$ and $72,350 \mathrm{~mm}$, respectively. The geometric model of the solution area was built using SOLIDWORKS according to the structure of the boiler. Appropriate simplifications were employed during the model construction. For example, the thicknesses of the water wall and the heat exchanger was considered as zero. Each corner of the furnace was equipped with 6 layers of primary air (PA) nozzles, including one layer for standby. Additionally, the specific layouts of auxiliary air (AUX) nozzles, close-coupled over fire air (CCOFA) nozzles, underfire air (UFA) nozzles and separated over fire air (SOFA) nozzles are shown in Figure 1b. 


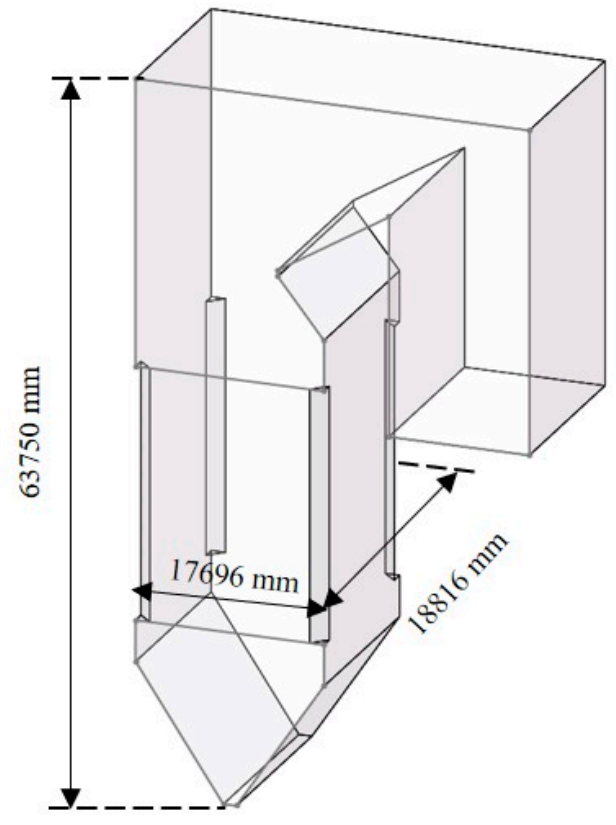

(a)

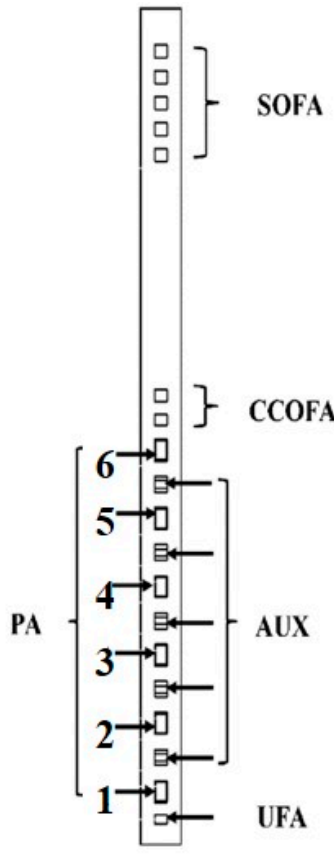

(b)

Figure 1. Structure of the boiler and arrangement of the nozzles: (a) utility boiler; (b) nozzle arrangement.

ICEM software was used to generate the hexahedral structured mesh system of the boiler. The mesh near the burner area was refined to improve the accuracy of the simulation results. Three sets of mesh systems were built, with the numbers of cells being 1,259,490, $1,695,378$ and 2,147,981 respectively. The grid-independence test showed that the difference between the two mesh systems with 1,695,378 and 2,147,981 cells was negligible. Therefore, considering the calculation accuracy and the calculation cost, the mesh system with $1,695,378$ cells was selected in this study. Figure 2 shows the mesh of the whole furnace and the mesh of the cross-section near the burner area.
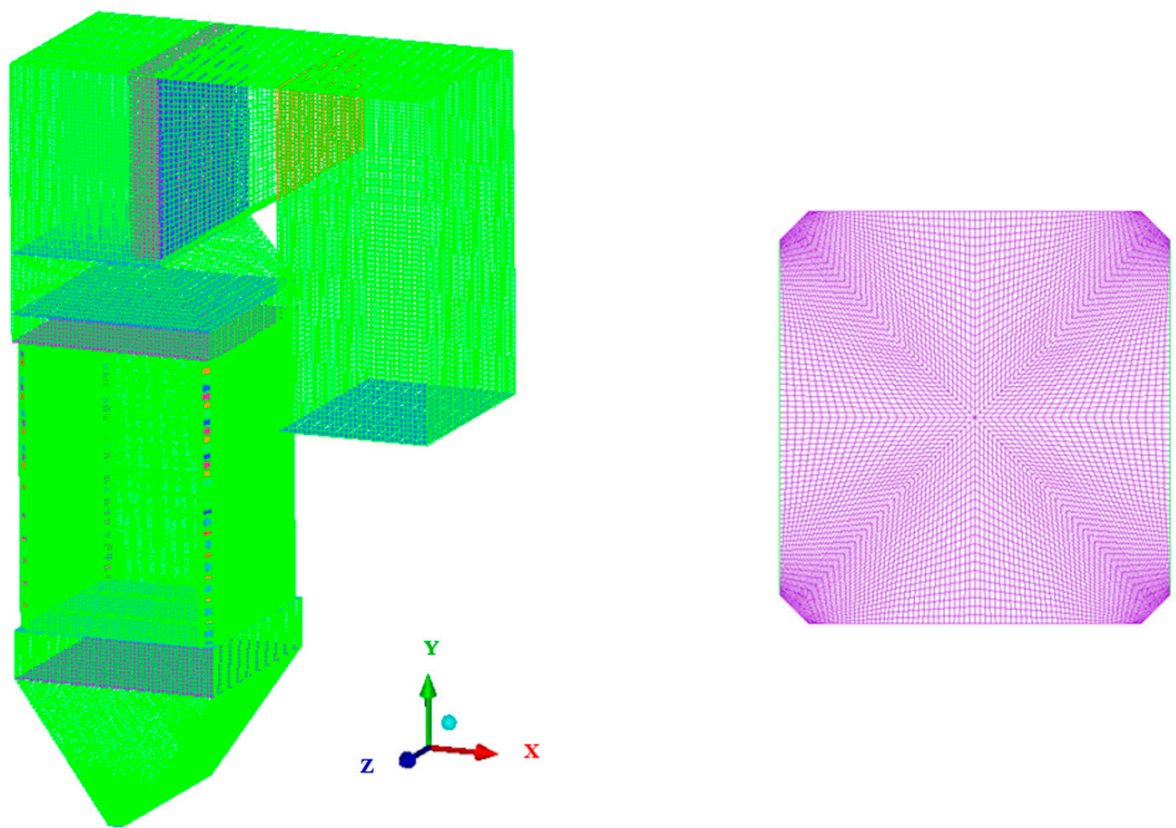

Figure 2. Mesh system of the boiler. 


\subsection{Coal Parameters and Boundary Conditions}

The coal used in this boiler was bituminous coal with a relatively high volatile content. The coal properties coal ash analysis can be found in Tables S1 and S2, respectively, in the Supporting Information. The size of coal particles followed the Rosin-Rammler distribution [24]. The minimum size, the maximum size and the average size of the coal particles were $1 \mu \mathrm{m}, 200 \mu \mathrm{m}$ and $61 \mu \mathrm{m}$, respectively.

This study can be divided into two parts. The first part focuses on the influence of the overall $\mathrm{Cl}$ concentration in the furnace; that is, the level of $\mathrm{Cl}$ in the coal. The second part focuses on the impacts of introducing a small amount of $\mathrm{Cl}$-containing compounds from SOFA nozzles on mercury species distributions. For all cases studied in this paper, the total excess air ratio and the excess air ratio in the primary zone were set as 1.2 and 0.8 , respectively. The coal feeding rate of the boiler was $60.08 \mathrm{~kg} \cdot \mathrm{s}^{-1}$, and the total air flow rate was $550.85 \mathrm{~kg} \cdot \mathrm{s}^{-1}$. The temperatures of primary air and secondary air (SA) were kept at $353 \mathrm{~K}$ and $612 \mathrm{~K}$, respectively. A mass flow inlet boundary was adopted for air nozzles during the calculation. More details about the operating conditions and the nozzle sizes are listed in Table 1.

Table 1. Operating parameters and boundary conditions.

\begin{tabular}{ccc}
\hline Parameters & Unit & Value \\
\hline coal feeding rate & $\mathrm{kg} \cdot \mathrm{s}^{-1}$ & 60.0833 \\
theoretical air requirement & $\mathrm{kg} \cdot \mathrm{kg}^{-1}$ & 7.6401 \\
total excess air ratio & - & 1.2 \\
excess air ratio in the primary & - & 0.8 \\
zone & $\mathrm{kg} \cdot \mathrm{s}^{-1}$ & 550.8512 \\
total air flow rate & - & 0.29 \\
PA rate & - & 0.51 \\
SA rate & - & 0.40 \\
SOFA rate & $\mathrm{K}$ & 353 \\
PA temperature & $\mathrm{K}$ & 612 \\
SA temperature & $\mathrm{kg} \cdot \mathrm{m}^{-3}$ & 1.0000 \\
PA density & $\mathrm{kg} \cdot \mathrm{m}^{-3}$ & 0.5768 \\
SA density & $\mathrm{mm}$ & 516 \\
Length of PA nozzles & $\mathrm{mm}$ & 218 \\
Height of UFA nozzles & $\mathrm{mm}$ & 254 \\
Height of CCOFA nozzles & $\mathrm{mm}$ & 490 \\
Height of SOFA nozzles & &
\end{tabular}

\section{Computational Modeling}

\subsection{Coal Combustion and $\mathrm{NO}_{x}$ Formation}

The combustion of coal is a complicated process, including preheating, drying, volatile release, ignition, combustion of volatiles, combustion of char and burnout, along with other physical and chemical processes, such as multiphase flow, heat radiation and heat convection. In this paper, FLUENT was used to simulate the flow, heat transfer and combustion processes in the furnace. The fluid flow was described using the standard k- $\varepsilon$ model, which has been widely used in the calculation of flow fields in boiler furnaces [25]. The two-competing-rate model was adopted to calculate the release of volatiles while the kinetic-diffusion-limited rate model was selected to calculate the char combustion process [26]. Additionally, the turbulent dispersion of coal particles was predicted using a stochastic tracking approach. The radiative transfer equation inside the furnace was solved using the discrete ordinate (DO) radiation model. The non-premixed combustion process was simplified and solved by applying the assumed-shape probability density function (PDF) approach [27]. As for the pressure-velocity coupling, the phase-coupled SIMPLE (PC-SIMPLE) algorithm was used to solve the equations [28]. After obtaining the velocity field, temperature field and concentration field of flue gas components in the furnace, the distributions of nitrogen oxides species were then calculated. The main species of nitrogen 
oxides generated during coal combustion are $\mathrm{NO}$ and $\mathrm{NO}_{2}$, among which $\mathrm{NO}$ accounts for more than $90 \%$. In addition, a small amount of $\mathrm{N}_{2} \mathrm{O}$ is formed. According to the formation path, $\mathrm{NO}_{x}$ can be divided into thermal $\mathrm{NO}_{x}$, fuel $\mathrm{NO}_{x}$ and prompt $\mathrm{NO}_{x}$. In terms of coalfired boilers, thermal $\mathrm{NO}_{x}$ and fuel $\mathrm{NO}_{x}$ are dominant while prompt $\mathrm{NO}_{x}$ is negligible [29]. In this study, the formation of thermal $\mathrm{NO}_{x}$ was described using the Zeldovich mechanism. The fuel $\mathrm{NO}_{x}$ was generated from volatile nitrogen and char nitrogen, with $\mathrm{HCN}$ and $\mathrm{NH}_{3}$ as the important intermediate products during the reaction.

\subsection{Homogeneous Oxidation of $\mathrm{Hg}^{0}$}

Based on the simulation results of coal combustion and $\mathrm{NO}_{x}$ formation, the homogeneous oxidation process of $\mathrm{Hg}^{0}$ was calculated using the eddy dissipation concept (EDC) model. The EDC model takes into account the specific chemical reaction mechanism in turbulence, which assumes that all chemical reactions take place in a very small turbulent structure $[30,31]$. It should be mentioned that tabulated chemistry modeling has been used by several researchers as an alternative method to EDC in some cases for better combination with the detailed mechanisms [32-34]. However, the accuracy of these gaseous flameletbased tabulated chemistry models would be reduced for coal combustion cases because the large coal particles may pass through the flame surface during the combustion process. Additionally, in order to consider the slow chemical processes, such as the generation of pollutants $\left(\mathrm{Hg}, \mathrm{NO}_{x}, \mathrm{SO}_{x}\right.$, etc.), the tabulated chemistry models need to be further extended to the unsteady form. Hence, we use the EDC model to carry out the numerical study for $\mathrm{Hg}$ reactions within the coal-fired utility boiler.

The homogeneous oxidation of $\mathrm{Hg}^{0}$ in coal-fired boilers is very complicated and affected by many factors, such as the temperature distribution and concentration of flue gas components. Moreover, as there is no sub-model for $\mathrm{Hg}$ reaction in FLUENT, a new $\mathrm{Hg}$ model must be built and imported for calculation. Some scholars believe that the reactions between mercury and chlorine are the most important for the homogeneous reaction of mercury. Based on this, a set of kinetic model containing 8 reversible elementary reactions was proposed [35]. Sliger et al. proposed that the most important factors affecting the homogeneous reaction of $\mathrm{Hg}$ were the $\mathrm{HCl}$ concentration, flue gas cooling rate and background gas composition, and found that the reaction between $\mathrm{Hg}$ and $\mathrm{Cl}$ was the main pathway for the oxidation of $\mathrm{Hg}^{0}$ [15]. The findings of $\mathrm{Xu}$ et al. showed that oxygen also plays a key role in the homogeneous reaction of mercury in addition to chlorine. Therefore, a kinetic model for homogeneous reactions of $\mathrm{Hg}$ was proposed, including $\mathrm{HgO}$-related elemental reactions [36]. According to the results of the sensitivity analysis, the reaction of $\mathrm{Hg}+\mathrm{ClO}=\mathrm{HgO}+\mathrm{Cl}$ is as important as the widely used reactions of $\mathrm{Hg}+\mathrm{Cl}_{2}=\mathrm{HgCl}+\mathrm{Cl}$ and $\mathrm{Hg}+\mathrm{HCl}=\mathrm{HgCl}+\mathrm{H}$.

Based on these previous studies, a novel $\mathrm{Hg}$ sub-model was proposed to achieve the coupling of thermodynamics, reaction kinetics and fluid dynamics for the homogeneous reactions of $\mathrm{Hg}$ in a full-scale boiler. Here, 32 elementary reactions were selected to describe the homogeneous oxidation process of $\mathrm{Hg}^{0}$ in a coal-fired utility boiler. The kinetic parameters of the reactions were obtained from the literature and have been verified in experimental studies [15]. The thermodynamic data for $\mathrm{Hg}$ and $\mathrm{HgCl}$ were obtained from the NIST database and imported into CHEMKIN together with elemental reactions. Then, the che file (shown in Table S2 in the Supporting Information), which can be used as the source file for the $\mathrm{Hg}$ sub-model in FLUENT, was generated by FitDat.

\section{Results and Discussion}

\subsection{Model Validation}

In order to validate the model used in this study, the simulation results were compared with the practical measured data from the coal-fired power plant. As shown in Figure 3, the flue gas temperature and the $\mathrm{O}_{2}$ concentration at the furnace outlet, the wall heat flux, the carbon content in fly ash and the $\mathrm{NO}_{x}$ emission were selected for comparison and validation. The largest error occurred in the carbon content in fly ash, with a relative error 
of $7.56 \%$. The relative errors of the temperature of the furnace outlet, $\mathrm{O}_{2}$ concentration at the furnace outlet, the wall heat flux and the $\mathrm{NO}_{x}$ emission were $2.70 \%, 3.62 \%, 3.35 \%$ and $1.41 \%$, respectively, which are acceptable results for the practical application of coal-fired utility boilers [37]. Hence, the model adopted in this study can simulate the flow, combustion and heat transfer processes well. In terms of the $\mathrm{Hg}$ distribution, the model was validated by comparing the simulation results with the findings from the literature, which can be found in Section 4.3, together with the discussion on the homogeneous reactions of $\mathrm{Hg}$.

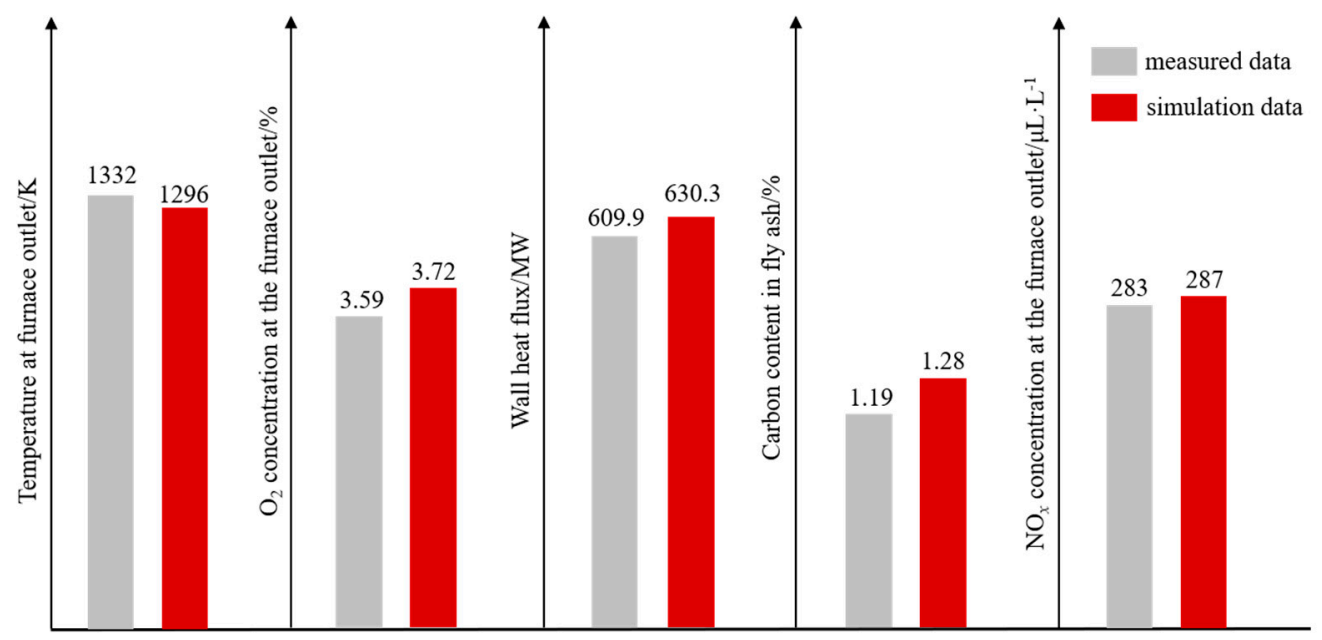

Figure 3. Model validation.

\subsection{Simulation Results before Considering Hg Reactions}

Before importing the mercury sub-model, the combustion process in the boiler was calculated using the non-premixed combustion model. After the temperature distribution, velocity distribution and flue gas components distribution were obtained, the $\mathrm{NO}_{x}$ model was activated. An imaginary coordinate was established within the boiler, which started from the bottom of the hopper and ended at the outlet of the calculation zone. A crosssection perpendicular to the coordinate was built every $1 \mathrm{~m}$ along the axis. The average flue gas temperature on each cross-section was calculated, with the results shown in Figure 4. It can be seen that the coordinate axis passed through the hopper area, the primary zone, the burnout area, the horizontal flue pass and the vertical flue pass. The fuel was injected into the furnace at the primary zone and mixed with the PA and SA, resulting in the intense combustion reaction and the rapid rise in flue gas temperature. Figure 5 shows the temperature contour of the cross-section at $25 \mathrm{~m}$, from which it can be seen that the ideal tangential combustion was formed in the primary zone. In the burnout zone, the introducing of SOFA caused further combustion of the unburned carbon, so the temperature of the flue gas increased again. Then, the temperature of the flue gas dropped gradually because of the heat transfer between the flue gas and the water wall or other heat exchangers. 


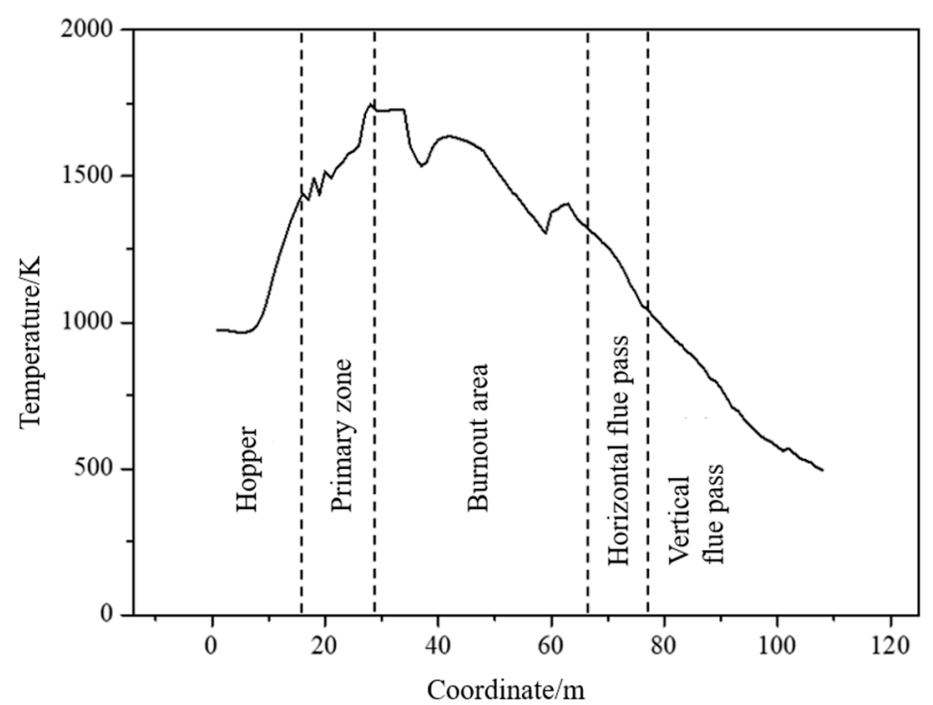

Figure 4. Flue gas temperature along the coordinates.

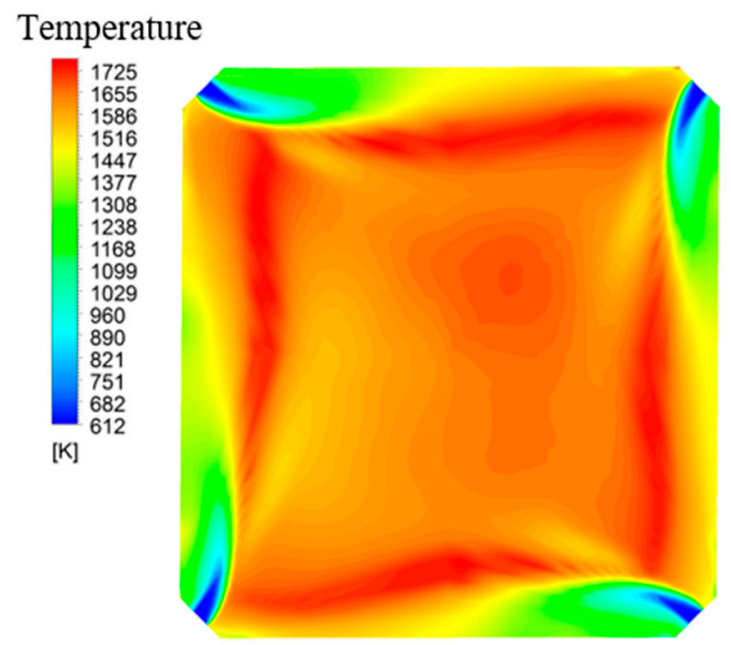

Figure 5. Temperature contour of the cross-section in the primary zone.

Figure 6 shows the velocity contour and distributions of the main flue gas components (including $\mathrm{O}_{2}, \mathrm{CO}_{2}, \mathrm{H}_{2} \mathrm{O}$ and $\mathrm{NO}$ ) within the boiler. As can be seen from Figure 6a, the flow field in the furnace showed good symmetry. The maximum velocity appeared in the vicinity of the nozzles, especially near the SOFA nozzles, while the flue gas velocity in the furnace center was relatively lower. The $\mathrm{O}_{2}$ carried by PA and SA was mainly consumed in the primary zone, leading to the lower $\mathrm{O}_{2}$ mole concentration in the center of the furnace, as shown in Figure 6 b. Part of the $\mathrm{O}_{2}$ was added through the SOFA nozzles for the oxidation of unburned carbon and $\mathrm{CO}$, after which the $\mathrm{O}_{2}$ concentration decreased gradually. Figure $6 \mathrm{c}$ presents the distribution of $\mathrm{CO}_{2}$. As the main product of coal combustion, the distribution of $\mathrm{CO}_{2}$ was almost opposite to that of $\mathrm{O}_{2}$. The $\mathrm{H}_{2} \mathrm{O}$ distribution is shown in Figure $6 \mathrm{~d}$. The release of the moisture in coal and the reaction of the $\mathrm{H}$ element during the combustion process were the main sources of $\mathrm{H}_{2} \mathrm{O}$ within the boiler. The $\mathrm{H}_{2} \mathrm{O}$ concentration was higher near the nozzles and in the primary zone, while lower in the central area of the burnout zone. $\mathrm{H}_{2} \mathrm{O}$ can react with chlorine to form $\mathrm{OH}$ through the equation of $\mathrm{Cl}+\mathrm{H}_{2} \mathrm{O}=\mathrm{OH}$ $+\mathrm{HCl}$, which would participate in the $\mathrm{Hg}$-related reactions. Therefore, it is necessary to consider the distribution of $\mathrm{H}_{2} \mathrm{O}$ in the furnace before the calculation of the $\mathrm{Hg}$ model. Similarly, nitrogen oxides could also be involved in the homogeneous reactions of mercury. The distribution of NO is shown in Figure 6e. The highest concentration of NO can be observed in the vicinity of the nozzles in the primary zone. 


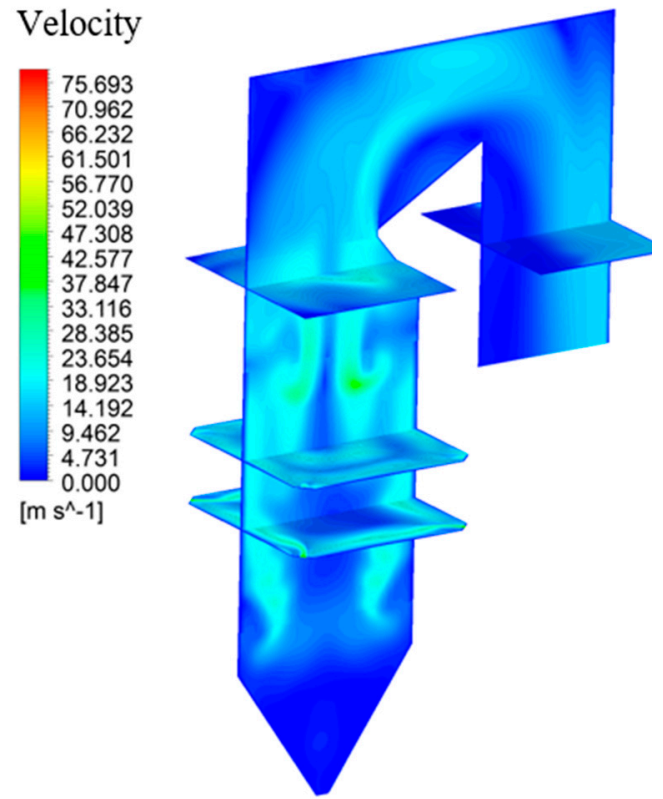

(a)

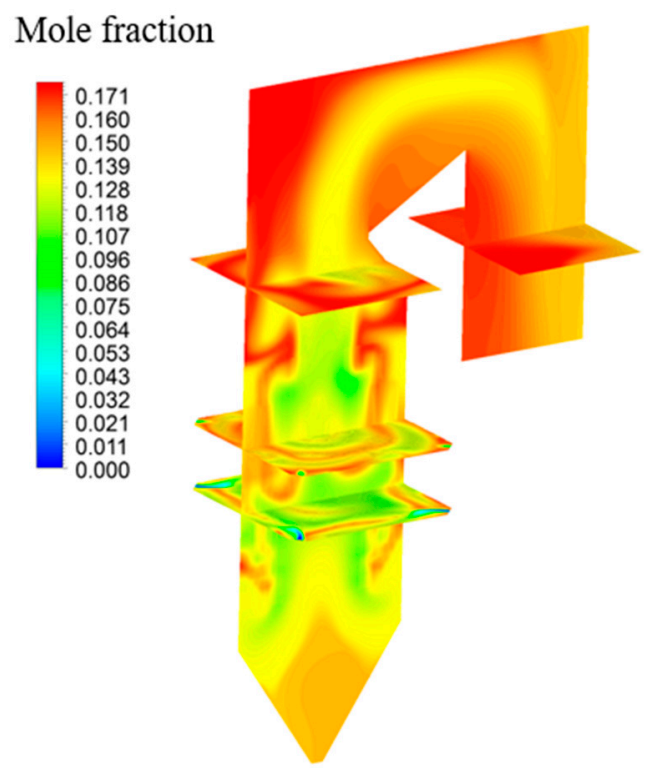

(c)

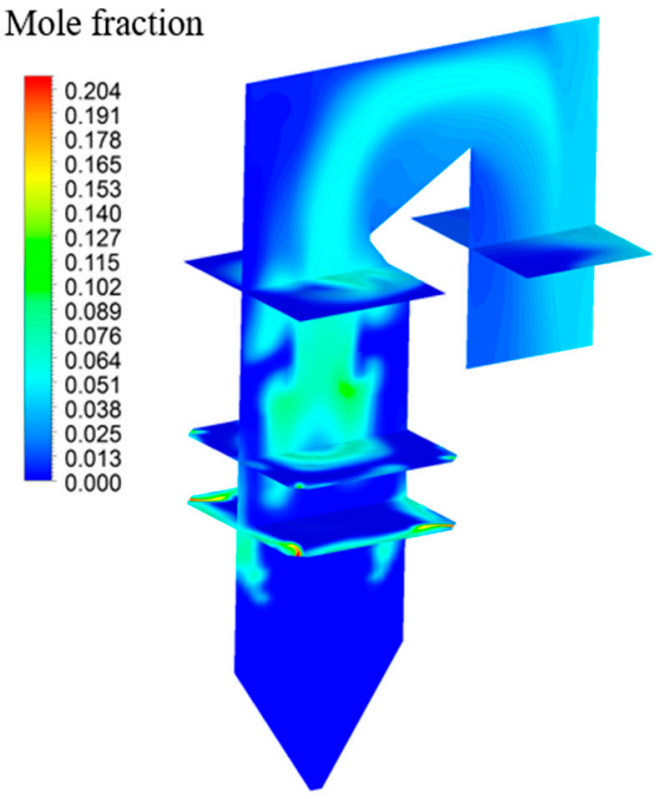

(b)

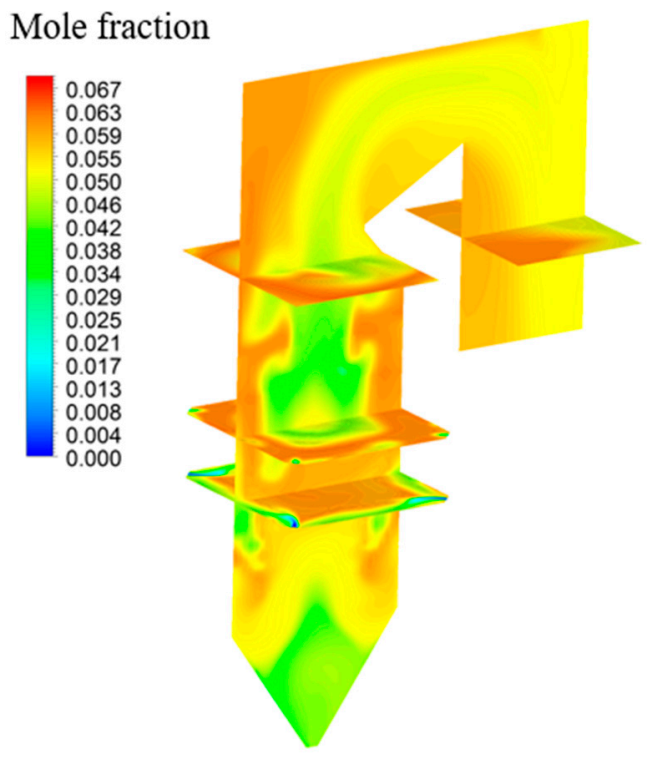

(d)

Figure 6. Cont. 


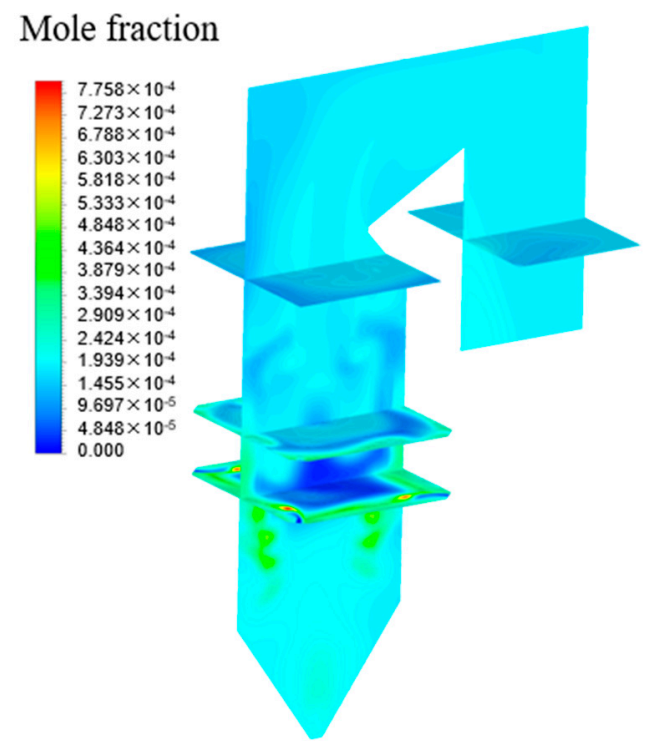

(e)

Figure 6. Velocity contour and distributions of the main flue gas components: (a) velocity contour; (b) $\mathrm{O}_{2}$ mole fraction; (c) $\mathrm{CO}_{2}$ mole fraction; (d) $\mathrm{H}_{2} \mathrm{O}$ mole fraction; (e) $\mathrm{NO}$ mole fraction.

\subsection{Effects of Chlorine Content in Coal on Homogeneous Reactions of $\mathrm{Hg}$}

Based on the results in Section 4.2, the homogeneous reactions of mercury species in coal-fired boilers were studied by utilizing the mercury sub-model. The reason why the Hg-related homogeneous reactions can be calculated using the post-treatment approach is that the contents of mercury species are very low. The mole concentrations of mercury species are orders of magnitude lower than those of other main flue gas components, such as $\mathrm{O}_{2}, \mathrm{CO}_{2}, \mathrm{H}_{2} \mathrm{O}$ and $\mathrm{NO}$, which means the influences of mercury-related reactions on the distributions of other flue gas components are negligible. In other word, the obtained simulation results in Section 4.2 are still applicable after considering the mercury sub-model.

Since the reactions between $\mathrm{Hg}$ and $\mathrm{Cl}$ are vital in the homogeneous oxidation of $\mathrm{Hg}^{0}$, it is of great significance to study the effects of chlorine content in coal on the distributions of mercury species in coal-fired boilers [38]. Previous studies have shown that the $\mathrm{Cl}$ element in coal would be released in the form of $\mathrm{HCl}$ after entering the furnace [39]. Additionally, $\mathrm{Hg}^{0}$ is the dominant mercury species under the high-temperature conditions of the primary zone. Therefore, $\mathrm{HCl}$ and $\mathrm{Hg}^{0}$ were introduced from the PA nozzles when setting boundary conditions. Two cases (case A and case B) were set up with various chlorine contents in coal. Specifically, low-chlorine coal was used in case A, while high-chlorine coal was used in case $\mathrm{B}$. The concentration of $\mathrm{HCl}$ in PA was set as $100 \mu \mathrm{L} \cdot \mathrm{L}^{-1}$ in case $\mathrm{A}$, which meant the $\mathrm{Cl}$ content in the coal in case A was $270 \mathrm{mg} \cdot \mathrm{kg}^{-1}$. The average concentration of $\mathrm{HCl}$ in the boiler can be calculated using Equations (1)-(7):

$$
\begin{gathered}
C_{A}(\mathrm{HCl})=C_{A 1}(\mathrm{HCl}) \times\left(V_{1} / V\right) \times\left(V / V_{y}\right) \\
V=\alpha \times V_{0} \\
V_{y}=V_{\mathrm{RO}_{2}}+V_{\mathrm{H}_{2} \mathrm{O}}+V_{\mathrm{N}_{2}}+V_{\mathrm{O}_{2}} \\
V_{\mathrm{RO}_{2}}=0.01866 \times\left(\mathrm{C}_{\mathrm{ar}}+0.375 \mathrm{~S}_{\mathrm{ar}}\right) \\
V_{\mathrm{H}_{2} \mathrm{O}}=0.111 \mathrm{H}_{\mathrm{ar}}+0.0124 \mathrm{M}_{\mathrm{ar}}+0.0161 V_{0} \\
V_{\mathrm{N}_{2}}=0.79 \alpha V_{0}+0.008 \mathrm{~N}_{\mathrm{ar}} \\
V_{\mathrm{O}_{2}}=0.21 \times(\alpha-1) V_{0}
\end{gathered}
$$


where $C_{A}(\mathrm{HCl})$ represents the average concentration of $\mathrm{HCl}$ in the boiler for case $\mathrm{A}$, $C_{A 1}(\mathrm{HCl})$ represents the concentration of $\mathrm{HCl}$ in $\mathrm{PA}$ for case $\mathrm{A}, V_{1}$ represents the flow rate of PA, $V$ represents the total air flow rate, $V_{0}$ represents the theoretical air flow rate and $V_{y}$ represents the flow rate of flue gas. Combined with the parameters in Table S1 and Table 1 , it can be calculated that $C_{A}(\mathrm{HCl})$ was about $23.5 \mu \mathrm{L} \cdot \mathrm{L}^{-1}$. In case $\mathrm{B}$, the concentration of $\mathrm{HCl}$ in PA was set as $400 \mu \mathrm{L} \cdot \mathrm{L}^{-1}$, which meant the $\mathrm{Cl}$ content in the high-Cl coal was $1080 \mathrm{mg} \cdot \mathrm{kg}^{-1}$. By replacing Equation (1) with the following equation, the average concentration of $\mathrm{HCl}$ in the boiler for case $\mathrm{B}$ can be obtained:

$$
C_{B}(\mathrm{HCl})=C_{B 1}(\mathrm{HCl}) \times \frac{V_{1}}{V} \times \frac{V}{V_{y}}
$$

where $C_{B}(\mathrm{HCl})$ represents the average concentration of $\mathrm{HCl}$ in the boiler for case $\mathrm{B}$ and $C_{B 1}(\mathrm{HCl})$ represents the concentration of $\mathrm{HCl}$ in $\mathrm{PA}$ for case $\mathrm{B}$. The value of $C_{B}(\mathrm{HCl})$ was about $94.0 \mu \mathrm{L} \cdot \mathrm{L}^{-1}$. In addition, the total mercury concentration in the boiler was set at $60 \mu \mathrm{g} \cdot \mathrm{m}^{-3}$ in both case A and case B. The $\mathrm{Hg}$ content in the coal can be calculated as $0.567 \mathrm{mg} \cdot \mathrm{kg}^{-1}$ in this study.

Figures 7-9 show the distributions of chlorine species in the boiler under various cases. It should be mentioned here based on case A that case $C$ was set up with $200 \mu \mathrm{L} \cdot \mathrm{L}^{-1}$ of $\mathrm{HCl}$ fed into the SOFA nozzles on the third layer (five layers of SOFA nozzles in total). The detailed results of case $C$ will be discussed later on (Section 4.4). In this section, we only focus on the simulation results of case $\mathrm{A}$ and case $\mathrm{B}$. Besides $\mathrm{HCl}$, the concentrations of $\mathrm{Cl}$ and $\mathrm{Cl}_{2}$ in case $\mathrm{B}$ were also obviously higher than those in case $\mathrm{A}$. Comparing the concentrations of these species, $\mathrm{HCl}$ is the dominant form of chlorine species in the whole furnace. The distributions of mercury species in the furnace are presented in Figures 10-13. The contours show that the homogeneous oxidation of $\mathrm{Hg}^{0}$ in the coal-fired boiler mainly occurred in the vertical flue pass, where the temperature was relatively lower. Because of the high temperature in the furnace zone, the concentrations of oxidized mercury species were at least two orders of magnitude lower than that of $\mathrm{Hg}^{0}$. At the exit of the boiler, $\mathrm{Hg}^{0}$ was still the dominant $\mathrm{Hg}$-containing species, while $\mathrm{HgCl}_{2}$ had the highest concentration among the oxidized mercury species. These results are in good agreement with the experimental data from the literature, indicating that the $\mathrm{Hg}$ sub-model used in this paper can simulate the homogeneous reactions of mercury in the furnace accurately [15,39].

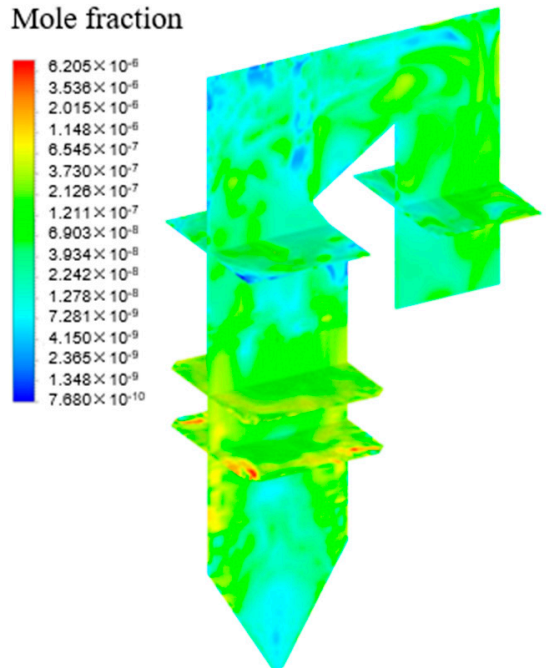

Case A

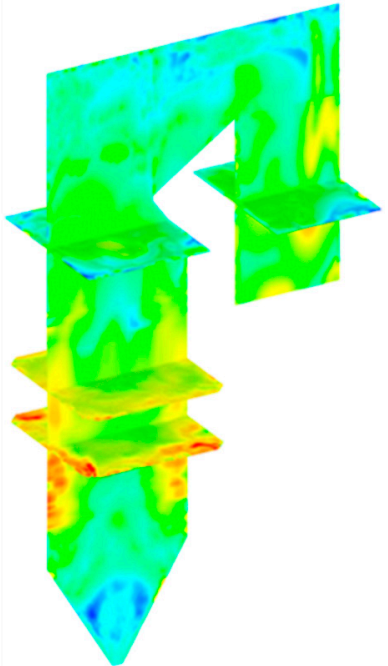

Case B

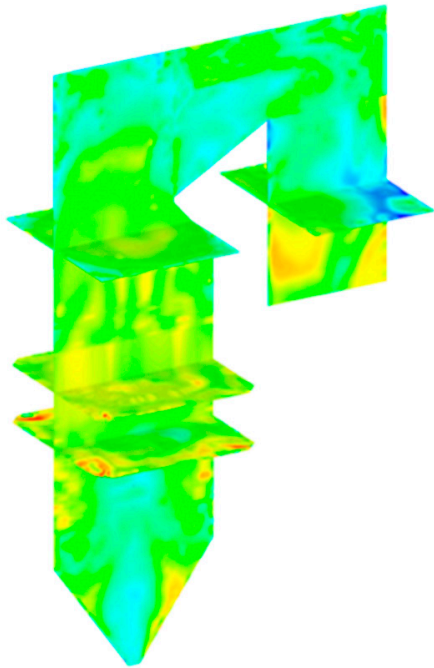

Case C

Figure 7. Distribution of $\mathrm{Cl}$ in various cases. 


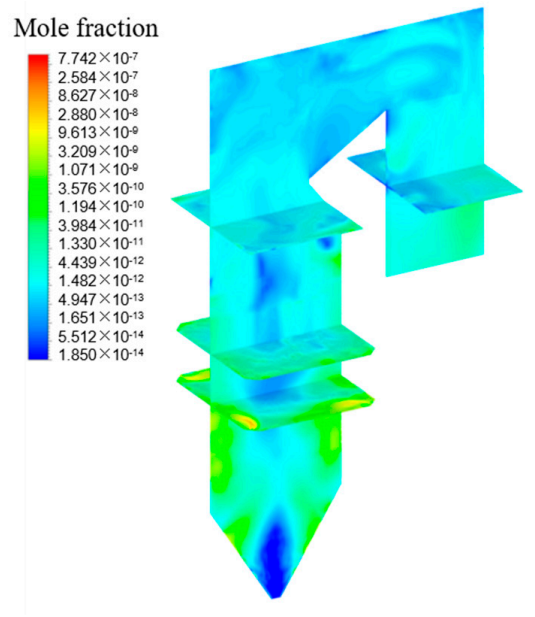

Case A

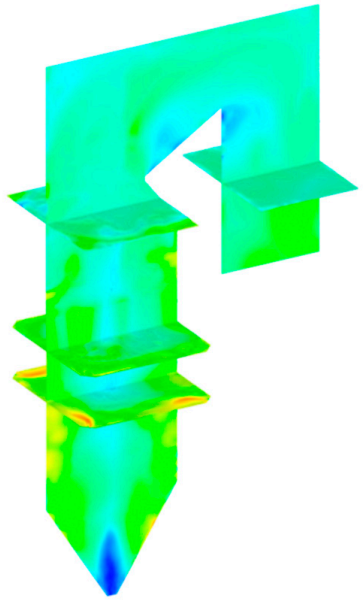

Case B

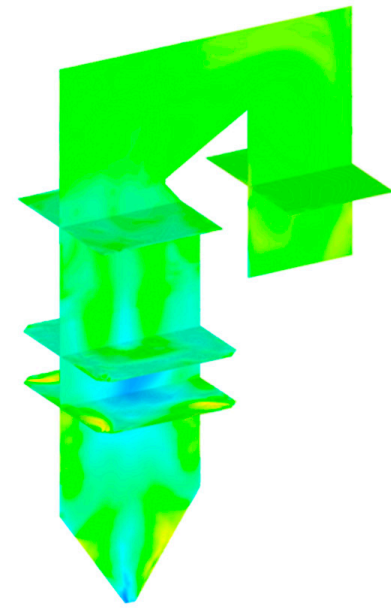

Case C

Figure 8. Distribution of $\mathrm{Cl}_{2}$ in various cases.
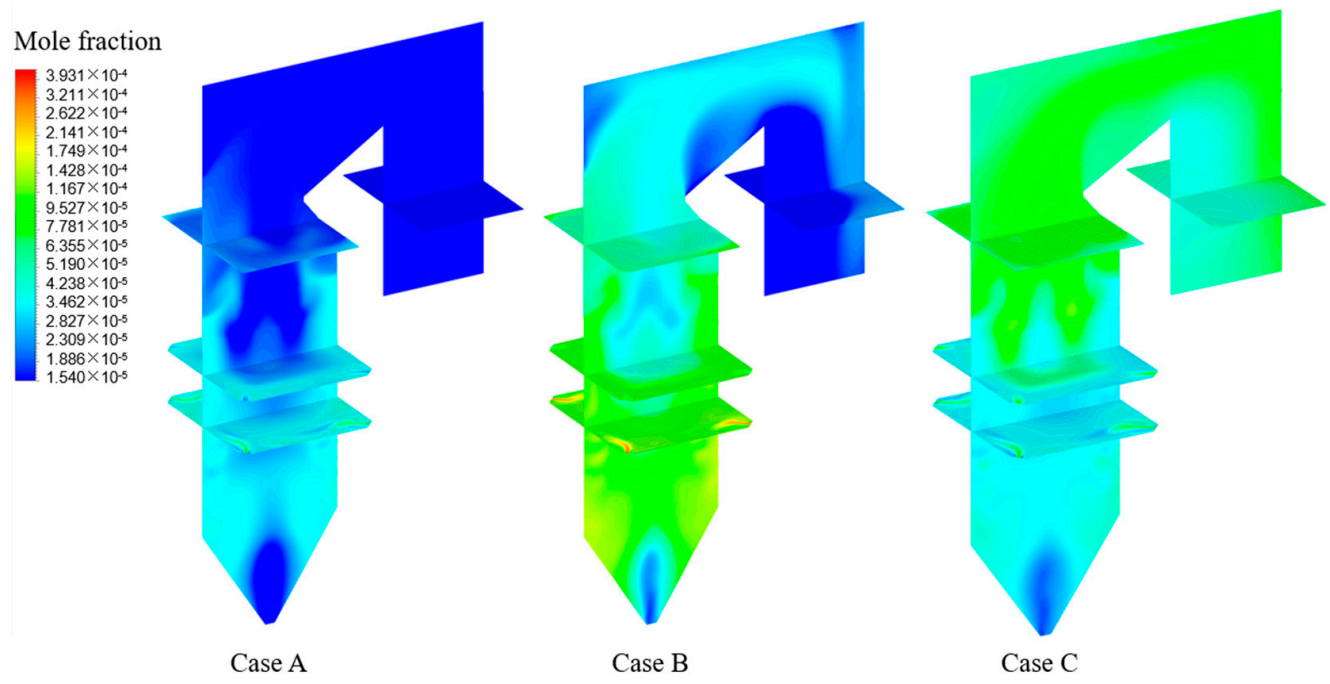

Figure 9. Distribution of $\mathrm{HCl}$ in various cases.

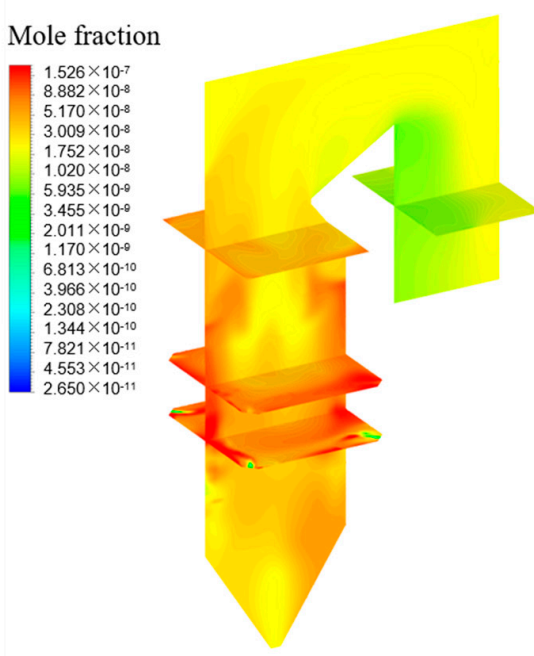

Case A

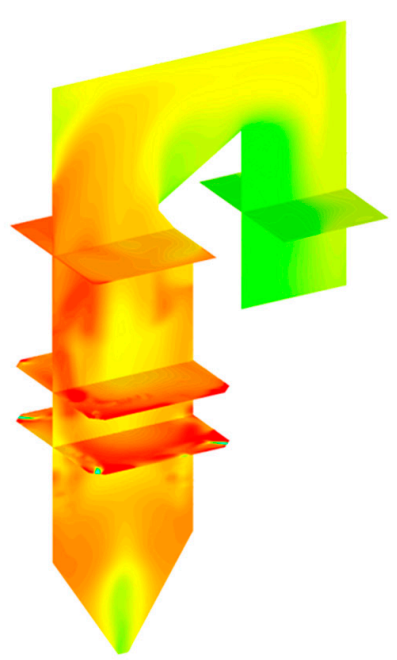

Case B

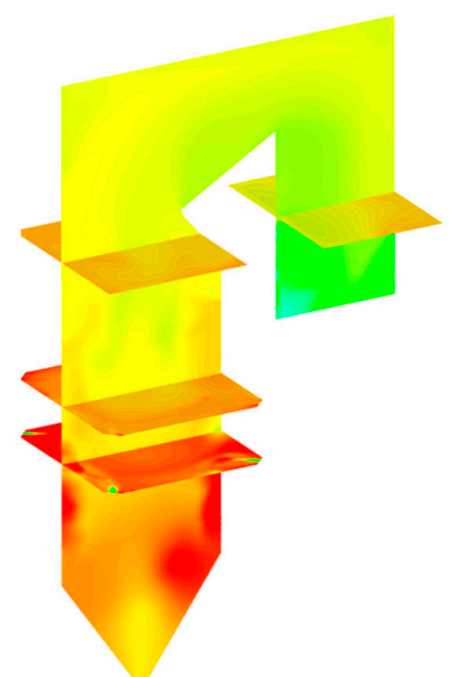

Case C

Figure 10. Distribution of $\mathrm{Hg}^{0}$ in various cases. 


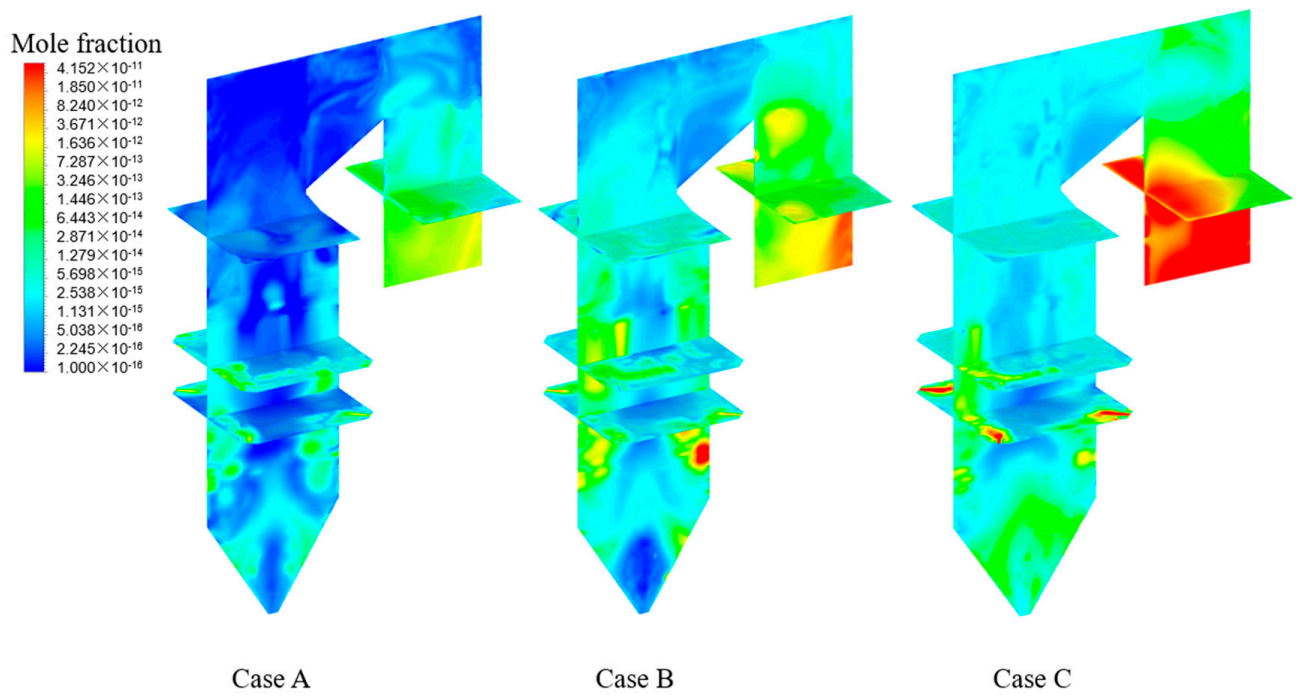

Figure 11. Distribution of $\mathrm{HgCl}$ in various cases.

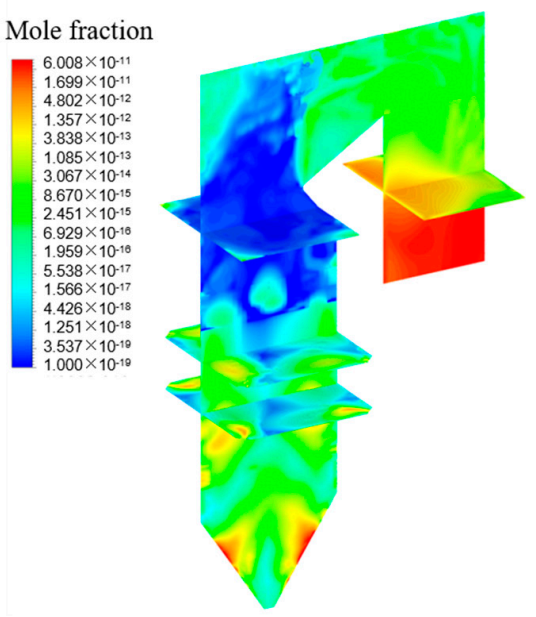

Case A

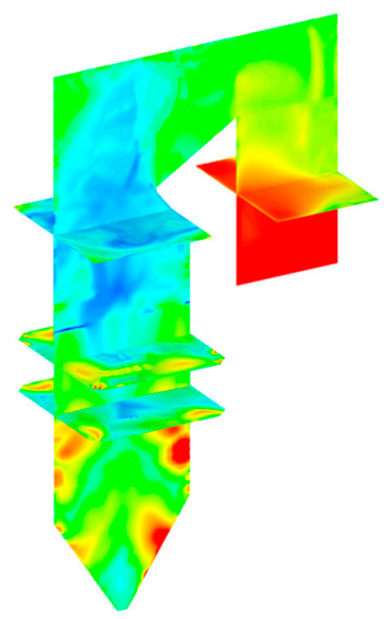

Case B

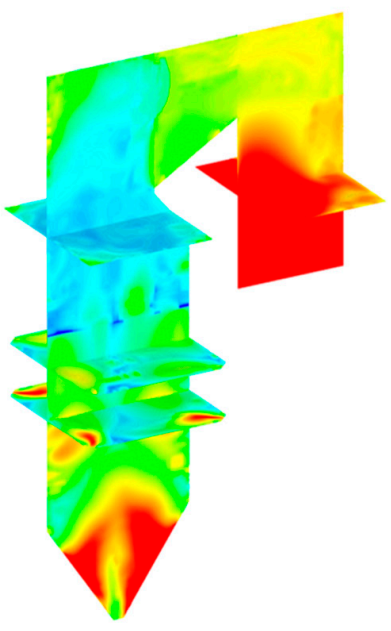

Case C

Figure 12. Distribution of $\mathrm{HgCl}_{2}$ in various cases.

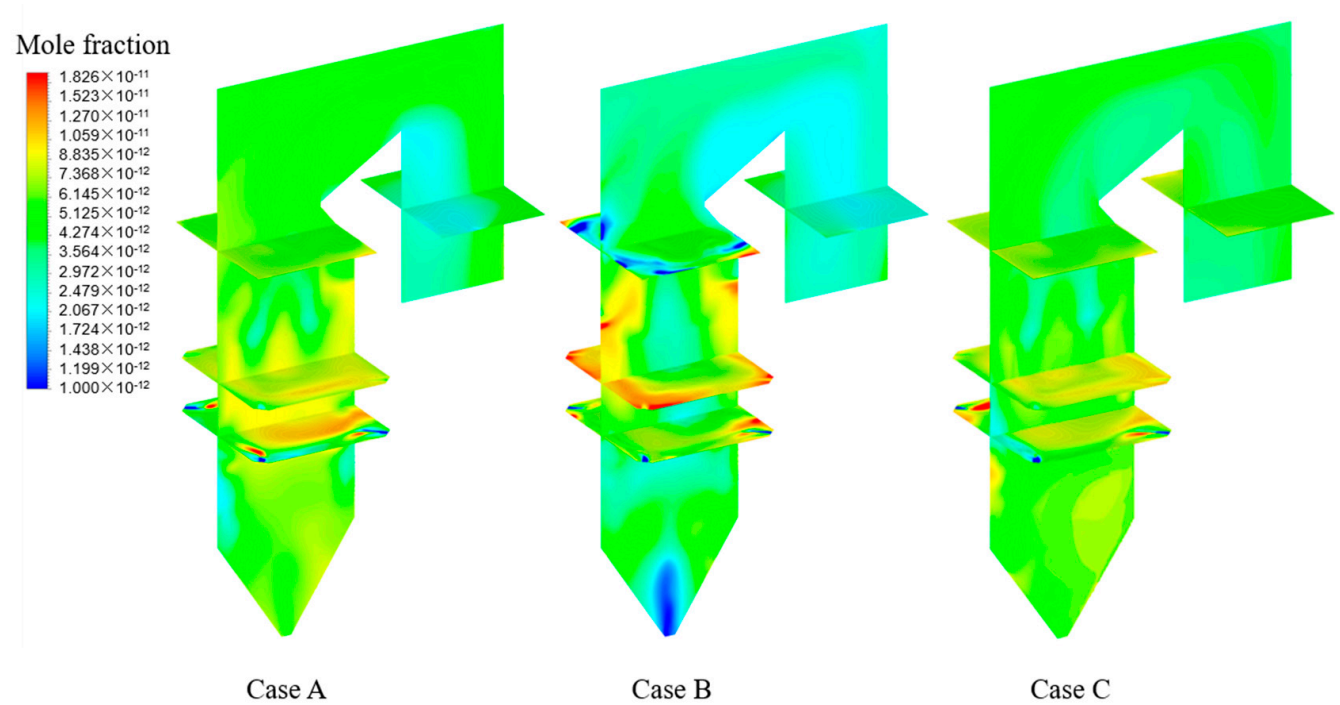

Figure 13. Distribution of $\mathrm{HgO}$ in various cases. 
The concentration of $\mathrm{Hg}^{0}$ was higher in the lower part of the furnace, which is consistent with the findings of Zhang et al. [39]. This can be attributed to the large relative atomic mass of $\mathrm{Hg}$. As the flue gas flowed to the upper part of the furnace, the horizontal flue pass and the vertical flue pass, the temperature of the flue gas also gradually decreased. The homogeneous oxidation of $\mathrm{Hg}^{0}$ then occurred, especially in the vertical flue pass.

In order to analyze the influence of chlorine content in coal on homogeneous reactions of $\mathrm{Hg}$ quantitatively, the ratios of $\mathrm{Hg}$ and its compounds at the boiler outlet were calculated, as listed in Table 2. In spite of the intense oxidation reactions of $\mathrm{Hg}^{0}$, the concentration of $\mathrm{Hg}^{0}$ remained above $90 \%$ in the vertical flue pass. Comparatively, the ratios of $\mathrm{Hg}^{0}$ in case A and case B were $99.039 \%$ and $95.196 \%$, respectively, which meant more $\mathrm{Hg}^{0}$ underwent homogeneous oxidation in the case with higher $\mathrm{Cl}$ content in coal.

Table 2. Ratios of $\mathrm{Hg}$ species at the boiler outlet in various cases.

\begin{tabular}{ccccc}
\hline Case & $\mathbf{H g}^{\mathbf{0}}$ & $\mathbf{H g C l}$ & $\mathbf{H g C l}_{\mathbf{2}}$ & $\mathbf{H g O}$ \\
\hline $\mathrm{A}$ & 99.039 & 0.008 & 0.922 & 0.031 \\
$\mathrm{~B}$ & 95.196 & 0.041 & 4.746 & 0.017 \\
$\mathrm{C}$ & 84.145 & 0.596 & 15.239 & 0.020 \\
\hline
\end{tabular}

The proportion of $\mathrm{HgCl}_{2}$ in oxidized mercury is shown in Figure 14 to better analyze the composition of the oxidized mercury. It can be seen that $\mathrm{HgCl}_{2}$ was the main component among the oxidized mercury species, which is consistent with the findings in the contours. The proportions of $\mathrm{HgCl}_{2}$ were higher than $95.9 \%$ in both cases. The results confirm that chlorine plays an important role in homogeneous oxidation of $\mathrm{Hg}^{0}$ in coal-fired boiler [40].

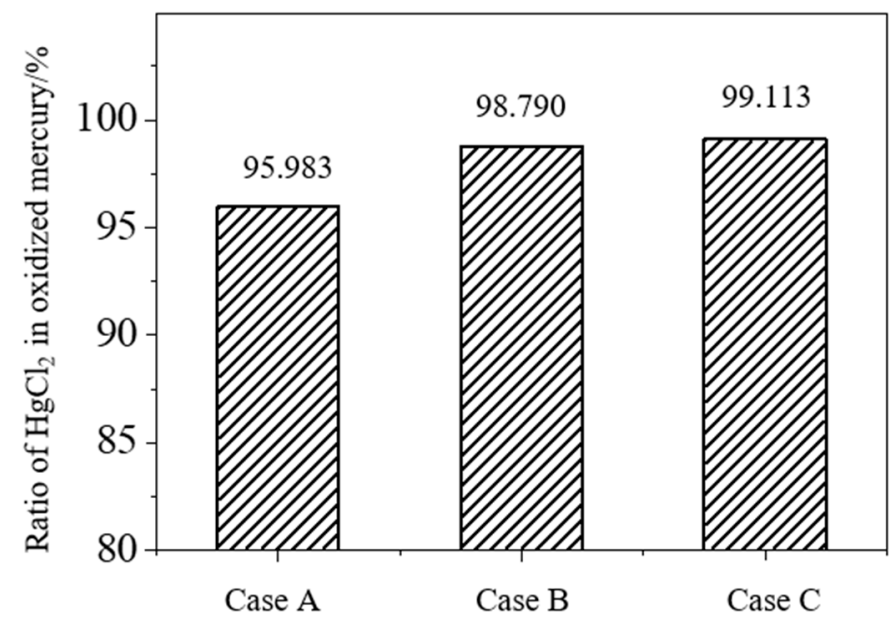

Figure 14. The proportion of $\mathrm{HgCl}_{2}$ in oxidized mercury species in various cases.

\subsection{Effects of Adding $\mathrm{HCl}$ on Homogeneous Reactions of $\mathrm{Hg}$}

Considering the important role of $\mathrm{Cl}$-containing compounds in homogeneous reactions of $\mathrm{Hg}$, a small amount of $\mathrm{HCl}$ can be added into boilers to promote the oxidation of $\mathrm{Hg}^{0}$. Nevertheless, the quantitative influence of $\mathrm{HCl}$ addition on the homogeneous reactions of $\mathrm{Hg}$ in full-scale utility boilers remains unclear. In this section, the distributions of chlorine-containing and mercury-containing species in the boiler before and after adding $\mathrm{HCl}$ are studied. According to the above analyses, the homogeneous reactions of $\mathrm{Hg}$ hardly occurred in the primary zone. Hence, supplementary $\mathrm{HCl}$ was added through the SOFA nozzles in the burnout area (case C). Combining Equations (2)-(7) and Equation (9), it can be calculated that the average concentration of $\mathrm{HCl}$ in the boiler in case $\mathrm{C}$ was about 
$39.7 \mu \mathrm{L} \cdot \mathrm{L}^{-1}$, which was about $69 \%$ higher than that in case $\mathrm{A}$, but still lower than in case B. The concentration of $\mathrm{Hg}$ was kept at $60 \mu \mathrm{g} \cdot \mathrm{m}^{-3}$ in case C.

$$
C_{C}(\mathrm{HCl})=C_{A}(\mathrm{HCl})+C_{\text {SOFA }-3}(\mathrm{HCl}) \times \frac{V_{\mathrm{SOFA}-3}}{V} \times \frac{V}{V_{y}}
$$

where $C_{C}(\mathrm{HCl})$ represents the average concentration of $\mathrm{HCl}$ in the boiler for case $\mathrm{C}$, $\mathrm{C}_{\mathrm{SOFA}-3}(\mathrm{HCl})$ represents the concentration of $\mathrm{HCl}$ in the third layer of SOFA nozzles and $V_{\text {SOFA-3 }}$ represents the air flow rate from the third layer of SOFA nozzles.

As shown in Figures 7-9, the concentrations of Cl-containing species in case $\mathrm{C}$ were significantly higher than those in case $\mathrm{A}$, especially in the burnout area. $\mathrm{HCl}$ was still the dominant component, while the concentration of $\mathrm{Cl}_{2}$ was the lowest. Figures 10-13 depict the contours of the $\mathrm{Hg}$-containing species. The concentration of $\mathrm{Hg}^{0}$ in the burnout area was reduced significantly after the addition of $\mathrm{HCl}$. In the whole boiler, especially in the vertical flue pass, the concentrations of $\mathrm{HgCl}_{2}$ and $\mathrm{HgCl}$ increased remarkably in case $\mathrm{C}$, while the impact of $\mathrm{HCl}$ addition on $\mathrm{HgO}$ was relatively slight. As the removal of elemental mercury is much more difficult than that of oxidized mercury, $\mathrm{HCl}$ addition is beneficial for $\mathrm{Hg}$ pollution control from coal-fired power plants burning low-Cl coal [41].

According to Table 2, after the addition of $\mathrm{HCl}$, the ratio of $\mathrm{Hg}^{0}$ decreased from $99 \%$ to about $84 \%$, while the ratio of $\mathrm{HgCl}_{2}$ increased by over 16 times and the content of $\mathrm{HgCl}$ also increased significantly. It is worth noting that the ratio of $\mathrm{Hg}^{0}$ in case $\mathrm{C}$ is even lower than that in case $\mathrm{B}$, which indicates that the homogeneous oxidation of $\mathrm{Hg}^{0}$ in case $\mathrm{C}$ was more intense than that in case $\mathrm{B}$, although the average $\mathrm{Cl}$ concentration in the boiler was lower. Therefore, it can be concluded that the addition of a small amount of $\mathrm{HCl}$ from the burnout area had an obvious promotion effect on the homogeneous oxidation of $\mathrm{Hg}^{0}$.

Zhuang et al. have experimentally studied the influence of adding $\mathrm{CaCl}_{2}$ on the oxidation of $\mathrm{Hg}^{0}$ in boilers [41]. They found that adding $600 \sim 1000 \mu \mathrm{L} \cdot \mathrm{L}^{-1} \mathrm{CaCl}_{2}$ would increase the concentration of chlorine in flue gas by $88.0 \sim 146.7 \mu \mathrm{L} \cdot \mathrm{L}^{-1}$. They reported that this level of chlorine concentration was common for boilers using high-Cl bituminous coal and would not cause serious corrosion problems. In this study, the average chlorine concentrations of flue gas in the three cases were $23.5 \mu \mathrm{L} \cdot \mathrm{L}^{-1}, 94.0 \mu \mathrm{L} \cdot \mathrm{L}^{-1}$ and $39.7 \mu \mathrm{L} \cdot \mathrm{L}^{-1}$, respectively. Compared with the results from Zhuang et al. [41], the $\mathrm{Cl}$ concentration in this paper was acceptable for practical engineering applications. Therefore, adding $\mathrm{HCl}$ into boilers fired with low-Cl coal can promote the homogeneous oxidation of $\mathrm{Hg}^{0}$ significantly without causing serious corrosion problems.

\section{Conclusions}

A numerical study was conducted on the homogeneous reactions of mercury in a coalfired utility boiler. For the first time, a novel mercury sub-model was built in a full-scale tangentially coal-fired boiler to achieve the coupling of thermodynamics, reaction kinetics and fluid dynamics. Since $\mathrm{Cl}$ is the most important element in the homogeneous oxidation of $\mathrm{Hg}^{0}$, the influence of the $\mathrm{Cl}$ content in coal on the homogeneous reaction of $\mathrm{Hg}$ in a boiler was studied. In addition, the quantitative effect of adding $\mathrm{HCl}$ on the homogeneous reactions of $\mathrm{Hg}$ within a full-scale boiler fired with low-Cl coal was investigated, which has not been reported before. The following conclusions can be drawn:

1. Ideal tangential combustion was achieved in the primary zone, causing the flue gas temperature to rise rapidly to $1748 \mathrm{~K}$. The velocity field showed good symmetry in the furnace. The concentrations of $\mathrm{H}_{2} \mathrm{O}(\sim 0.06$ in mole fraction $)$ and $\mathrm{NO}\left(\sim 7 \times 10^{-4}\right.$ in mole fractions) were higher in the vicinity of the primary air nozzles;

2. More elemental mercury $(\sim 4.8 \%)$ was converted to oxidized mercury through homogeneous reactions when high- $\mathrm{Cl}$ coal was burned, which is conducive to mercury pollution control. $\mathrm{HCl}$ was the main component of chlorine species in the boiler, while the concentrations of $\mathrm{Cl}$ and $\mathrm{Cl}_{2}$ were low. The homogeneous reactions of $\mathrm{Hg}$ mainly occurred in the vertical flue pass with lower temperature. At the boiler exit, $\mathrm{Hg}^{0}$ remained 
the dominant $(>95.2 \%) \mathrm{Hg}$-containing species, while $\mathrm{HgCl}_{2}$ accounted for the largest proportion $(>95.9 \%)$ of the oxidized mercury;

3. Adding $\mathrm{HCl}$ from the separated overfire air nozzles can promote the homogeneous oxidation of $\mathrm{Hg}^{0}$ remarkably. The ratio of $\mathrm{HgCl}_{2}$ increased by over 16 times. It is worth noting that even after introducing $\mathrm{HCl}$ into the boilers using low- $\mathrm{Cl}$ coal, the average concentration of $\mathrm{HCl}\left(39.7 \mu \mathrm{L} \cdot \mathrm{L}^{-1}\right)$ was still lower than the common cases when high-Cl coal was fired. Hence, adding $\mathrm{HCl}$ is a safe and effective method of $\mathrm{Hg}$ pollution control from the perspectives of chlorine corrosion and $\mathrm{Hg}^{0}$ oxidation.

In general, the results of this study are of significance in understanding the homogeneous reactions between $\mathrm{Hg}$ and $\mathrm{Cl}$ within a full-scale utility boiler. The methodology used in this numerical work paves the way for the further development of advanced $\mathrm{Hg}$ models. The combination of detailed tabulated chemistry modeling and coal combustion deserves more attention in the future.

Supplementary Materials: The following are available online at https://www.mdpi.com/article/10 .3390/en15020446/s1: Table S1: Coal properties. Table S2: Coal ash composition analysis. Table S3. Source file of $\mathrm{Hg}$ sub-model.

Author Contributions: Conceptualization, Q.L.; methodology, Q.L.; software, Q.L. and X.L.; validation, X.L.; investigation, Q.L.; resources, C.W.; data curation, Q.L.; writing-original draft preparation, Q.L.; writing-review and editing, C.W.; supervision, C.W.; project administration, D.C.; funding acquisition, Q.L. All authors have read and agreed to the published version of the manuscript.

Funding: This work was supported by the Science and Technology Project of Beilin District, Xi'an (No. GX2120).

Conflicts of Interest: The authors declare no conflict of interest.

\section{References}

1. Fernández-Miranda, N.; Rodríguez, E.; Lopez-Anton, M.A.; García, R.; Martínez-Tarazona, M.R. A new approach for retaining mercury in energy generation processes: Regenerable carbonaceous sorbents. Energies 2017, 10, 1311. [CrossRef]

2. Lv, Q.; Cai, M.; Wang, C.A.; He, Y.; Che, D.F. Investigation on elemental mercury removal by cerium modified semi-coke. J. Energy Inst. 2020, 93, 666-678. [CrossRef]

3. Li, X.; Teng, Y.; Zhang, K.; Peng, H.; Cheng, F.; Yoshikawa, K. Mercury migration behavior from flue gas to fly ashes in a commercial coal-fired CFB power plant. Energies 2020, 13, 1040. [CrossRef]

4. Yang, Y.; Liu, J.; Wang, Z. Reaction mechanisms and chemical kinetics of mercury transformation during coal combustion. Prog. Energ. Combust. 2020, 79, 100844. [CrossRef]

5. Contreras, M.L.; Ganesh, N.; Rodilla, I.; Bahillo, A. Assess of biomass co-firing under oxy-fuel conditions on Hg speciation and ash deposit formation. Fuel 2018, 215, 395-405. [CrossRef]

6. Galbreath, K.C.; Zygarlicke, C.J. Mercury transformations in coal combustion flue gas. Fuel Process. Technol. 2000, 65, 289-310. [CrossRef]

7. Senior, C.L.; Sarofim, A.F.; Zeng, T.F.; Helble, J.J.; Mamani-Paco, R. Gas-phase transformations of mercury in coal-fired power plants. Fuel Process. Technol. 2000, 63, 197-213. [CrossRef]

8. Frandsen, F.; Dam-Johansen, K.; Rasmussen, P. Trace elements from combustion and gasification of coal-An equilibrium approach. Prog. Energ. Combust. 1994, 20, 115-138. [CrossRef]

9. Chen, L.; Duan, Y.; Zhuo, Y.; Yang, L.G.; Zhang, L.; Yang, X.H.; Yao, Q.; Jiang, Y.M.; Xu, X.C. Mercury transformation across particulate control devices in six power plants of China: The co-effect of chlorine and ash composition. Fuel 2007, 86, 603-610.

10. Ito, S.; Yokoyama, T.; Asakura, K. Emissions of mercury and other trace elements from coal-fired power plants in Japan. Sci. Total Environ. 2006, 368, 397-402. [CrossRef] [PubMed]

11. Pavlish, J.H.; Holmes, M.J.; Benson, S.A.; Crocker, C.R.; Galbreath, K.C. Application of sorbents for mercury control for utilities burning lignite coal. Fuel Process. Technol. 2004, 85, 563-576. [CrossRef]

12. Laudal, D.L.; Brown, T.D.; Nott, B.R. Effects of flue gas constituents on mercury speciation. Fuel Process. Technol. 2000, 65, 157-165. [CrossRef]

13. Wang, J.S.; Clements, B.; Zanganeh, K. An interpretation of flue-gas mercury speciation data from a kinetic point of view. Fuel 2003, 82, 1009-1011. [CrossRef]

14. Jiao, Y.; Dibble, T.S. First kinetic study of the atmospherically important reactions $\mathrm{BrHg}+\mathrm{NO}_{2}$ and BrHg+HOO. Phys. Chem. Chem. Phys. 2017, 19, 1826-1838. [CrossRef]

15. Sliger, R.N.; Kramlich, J.C.; Marinov, N.M. Towards the development of a chemical kinetic model for the homogeneous oxidation of mercury by chlorine species. Fuel Process. Technol. 2000, 65, 423-438. [CrossRef] 
16. Galbreath, K.C.; Zygarlicke, C.J.; Tibbetts, J.E.; Schulz, R.L.; Dunham, G.E. Effects of $\mathrm{NO}_{x}, \alpha-\mathrm{Fe}_{2} \mathrm{O}_{3}, \gamma-\mathrm{Fe}_{2} \mathrm{O}_{3}$, and $\mathrm{HCl}$ on mercury transformations in a 7-kW coal combustion system. Fuel Process. Technol. 2004, 86, 429-448. [CrossRef]

17. Wang, F.; Li, G.; Wang, S.; Wu, Q.; Zhang, L. Modeling the heterogeneous oxidation of elemental mercury by chlorine in flue gas. Fuel 2020, 262, 116506. [CrossRef]

18. Lv, Q.; Wang, C.A.; He, Y.; Cai, M.; Che, D.F. Elemental mercury removal over $\mathrm{CeO}_{2} / \mathrm{TiO}_{2}$ catalyst prepared by sol-gel method. Appl. Sci. 2020, 10, 2706. [CrossRef]

19. Zhao, L.; Wu, Y.W.; Han, J.; Wang, H.X.; Liu, D.J.; Lu, Q.; Yang, Y.P. Density functional theory study on mechanism of mercury removal by $\mathrm{CeO}_{2}$ modified activated carbon. Energies 2018, 11, 2872. [CrossRef]

20. Ma, L.; Chen, X.; Liu, J.; Fang, Q.; Zhang, C.; Li, Y.; Mao, R.; Ren, L.; Zhang, P.; Chen, G. Insights into the causes and controlling strategies of gas temperature deviation in a $660 \mathrm{MW}$ tangentially fired tower-type boiler. Appl. Therm. Eng. 2021, 196, 117297. [CrossRef]

21. Liu, X.; Zhang, J.; Tan, H.; Mo, Q.; Wang, X.; Wang, Y. Numerical and experimental study on co-firing of low volatile coal in a 330 MW tangentially fired boiler. J. Energy Inst. 2021, 96, 242-250. [CrossRef]

22. Sankar, G.; Chandra, S.D.; Santhosh, K.D.; Balasubramanian, K.R. Numerical simulation of the heat transfer and $\mathrm{NO}_{x}$ emissions in a $660 \mathrm{MW}$ tangentially fired pulverised-coal supercritical boiler. Heat Mass Transfer 2020, 56, 2693-2709.

23. Jiang, Y.; Lee, B.-H.; Oh, D.-H.; Jeon, C.-H. Optimization of operating conditions to achieve combustion stability and reduce $\mathrm{NO}_{x}$ emission at half-load for a 550-MW tangentially fired pulverized coal boiler. Fuel 2021, 306, 121727. [CrossRef]

24. Che, D. Boilers-Theory, Design and Operation, 1st ed.; Xi'an Jiaotong University Press: Xi'an, China, 2008 ; p. 245.

25. Vuthaluru, R.; Vuthaluru, H.B. Modelling of a wall fired furnace for different operating conditions using FLUENT. Fuel Process. Technol. 2006, 87, 633-639. [CrossRef]

26. Hurt, R.; Sun, J.K.; Lunden, M. A kinetic model of carbon burnout in pulverized coal combustion. Combust. Flame 1998, 113, 181-197. [CrossRef]

27. Haas, J.; Tamura, M.; Weber, R. Characterization of coal blends for pulverized fuel combustion. Fuel 2001, 80, 1317-1323. [CrossRef]

28. Vasquez, S.A.; Ivanov, V.A. A Phase Coupled Method for Solving Multiphase Problems on Unstructured Meshes. In Proceedings of the ASME 2000 Fluids Engineering Division Summer Meeting, Boston, MA, USA, 11-15 June 2000.

29. Hill, S.C.; Smoot, L.D. Modeling of nitrogen oxides formation and destruction in combustion systems. Prog. Energ. Combust. 2000, 26, 417-458. [CrossRef]

30. Magnussen, B.F. On the Structure of Turbulence and a Generalized Eddy Dissipation Concept for Chemical Reaction in Turbulent Flow. In Proceedings of the 19th Aerospace Sciences Meeting, St. Louis, MO, USA, 12-15 January 1981.

31. Gran, I.R.; Magnussen, B.F. A numerical study of a bluff-body stabilized diffusion flame. Part 2. Influence of combustion modeling and finite-rate chemistry. Combust. Sci. Technol. 1996, 119, 191. [CrossRef]

32. Mayrhofer, M.; Koller, M.; Seemann, P.; Prieler, R.; Hochenauer, C. Evaluation of flamelet-based combustion models for the use in a flameless burner under different operating conditions. Appl. Therm. Eng. 2021, 183, 116190. [CrossRef]

33. Sorrentino, G.; Ceriello, G.; Cavaliere, A.; de Joannon, M.; Ragucci, R. Thermo-chemical manifold reduction for tabulated chemistry modeling. Temperature and dilution constraints for smooth combustion reactors. Proc. Combust. Inst. 2021, 38, 5393-5402. [CrossRef]

34. Wen, X.; Luo, Y.; Wang, H.; Luo, K.; Jin, H.; Fan, J. A three mixture fraction flamelet model for multi-stream laminar pulverized coal combustion. Proc. Combust. Inst. 2018, 37, 2901-2910. [CrossRef]

35. Pan, H.Y.; Minet, R.G.; Benson, S.W.; Tsotsis, T.T. Process for converting hydrogen-chloride to chlorine. Ind. Eng. Chem. Res. 1994, 33, 2996-3003. [CrossRef]

36. Xu, M.H.; Qiao, Y.; Zheng, C.G.; Li, L.C.; Liu, J. Modeling of homogeneous mercury speciation using detailed chemical kinetics. Combust. Flame 2003, 132, 208-218. [CrossRef]

37. Liu, H.; Liu, Y.; Yi, G.; Li, N.; Che, D. Effects of air staging conditions on the combustion and $\mathrm{NO}_{x}$ emission characteristics in a $600 \mathrm{MW}$ wall fired utility boiler using lean coal. Energ. Fuel. 2013, 27, 5831-5840. [CrossRef]

38. Brown, T.D.; Smith, D.N.; O'Dowd, W.J.; Hargis Jr, R.A. Control of mercury emissions from coal-fired power plants: A preliminary cost assessment and the next steps for accurately assessing control costs. Fuel Process. Technol. 2000, 65, 311-341. [CrossRef]

39. Zhang, H.; Wang, M.; Wu, H.; Yang, H. Numerical simulation on mercury emission and transformation of occurrence state in a 410 t/h coal-fired boiler. Proc. CSEE 2012, 32, 65-70.

40. Kellie, S.; Cao, Y.; Duan, Y.; Li, L.; Chu, P.; Mehta, A.; Carty, R.; Riley, J.T.; Pan, W.-P. Factors affecting mercury speciation in a $100 \mathrm{MW}$ coal-fired boiler with low-NO $\mathrm{N}_{x}$ burners. Energy Fuels 2005, 19, 800-806. [CrossRef]

41. Zhuang, Y.; Thompson, J.S.; Zygarlicke, C.J.; Pavlish, J.H. Impact of calcium chloride addition on mercury transformations and control in coal flue gas. Fuel 2007, 86, 2351-2359. [CrossRef] 